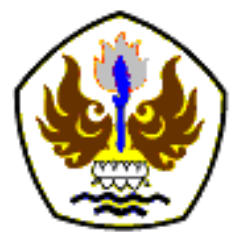

INFOMATEK

Volume 20 Nomor 2 Desember 2018

\title{
ANALISIS STATISTIK VARIABEL INTERNAL PERUSAHAAN DAERAH AIR MINUM DI INDONESIA YANG BERPENGARUH PADA PENINGKATAN CAKUPAN PELAYANAN
}

\author{
Budi Heri Pirngadi ${ }^{\star}$, Furi Sari Nurwulandari \\ Program Studi Perencanaan Wilayah dan Kota \\ Fakultas Teknik - Universitas Pasundan
}

\begin{abstract}
Abstrak: Tingkat cakupan pelayanan air minum perpipaan di Indonesia yang dilakukan oleh perusahaan daerah air minum (PDAM) pada tahun 2016 secara rata-rata masih pada kisaran 40\%. Angka ini masih jauh dibawah target pelayanan air minum perpipaan sebesar $60 \%$ di tahun 2019. Diperlukan upaya intensif untuk dapat mencapai target tersebut. Berdasarkan analisis statistik apabila PDAM ingin meningkatkan cakupan pelayanan, maka perlu dilakukan perbaikan pada variabel-variabel internal PDAM, yaitu; rasio operasi, efisiensi produksi, kualitas air minum, tingkat kehilangan air, konsumsi air pelanggan dan rasio pegawai/1000 pelanggan. Upaya perbaikan akan mendapatkan hasil yang berarti jika dilakukan secara simultan karena apabila perbaikan secara parsial hasil yang didapatkan tidak terlalu berarti.
\end{abstract}

Kata kunci: Cakupan pelayanan, variabel internal, PDAM

\section{PENDAHULUAN}

Rencana pembangunan jangka menengah 2015-2018 sebagaimana telah ditetapkan dalam Peraturan Presiden Republik Indonesia Nomor 2 Tahun 2015 Tentang Rencana Pembangunan Jangka Menengah Nasional Tahun 2015 - 2019 yang mengamanatkan bahwa pada akhir tahun 2019 seluruh penduduk Indonesia telah mendapatkan akses air minum bekualitas (layak).

\footnotetext{
*) budipirngadie@yahoo.com
}

Pertama diterima : 30 Januari 2018

Direvisi : 31 Januari 2018

Disetujui untuk publikasi: 10 Juli 2018
Berdasarkan definisi dari Badan Pusat Statistik, yang dimaksud dengan air minum yang berkualitas (layak) adalah air minum yang terlindung meliputi air ledeng (keran), keran umum, hidran umum, terminal air, penampungan air hujan (PAH) atau mata air dan sumur terlindung, sumur bor atau sumur pompa, yang jaraknya minimal $10 \mathrm{~m}$ dari pembuangan kotoran, penampungan limbah dan pembuangan sampah. Tidak termasuk air kemasan, air dari penjual keliling, air yang dijual melalui tangki, air sumur dan mata air tidak terlindung. Proporsi rumah tangga dengan akses berkelanjutan terhadap air minum layak adalah perbandingan antara 
rumah tangga dengan akses terhadap sumber air minum berkualitas (layak) dengan rumah tangga seluruhnya, dinyatakan dalam persen.

Data terakhir dari BPS, pada tahun 2016 akses air minum berkualitas di Indonesia adalah sebesar $71,14 \%$. Hal itu berarti untuk mencapai universal akses sebesar 100\%, pada akhir tahun 2019 masih terdapat kekurangan sebesar 28,86\%. Data akses air minum berkualitas yang masih dikisaran $70 \%$ itu berimplikasi terhadap tingginya angka keterjangkitan penyakit yang ditularkan melalui media air (waterborne disease) seperti penyakit diare.

Penyakit diare merupakan penyakit endemis di Indonesia dan juga merupakan penyakit potensial KLB yang sering disertai dengan kematian. Pada tahun 2015 terjadi 18 kali KLB Diare yang tersebar di 11 provinsi, 18 kabupaten/kota, dengan jumlah penderita 1213 orang dan kematian 30 orang (Case Fatality rate/CFR 2,47\%) (Kementerian Kesehatan RI, [1]).

Untuk dapat mencapai target universal akses, maka pemerintah dituntut untuk melakukan upaya intensif diantaranya dengan meningkatkan cakupan pelayanan air minum perpipaan yang dilakukan oleh perusahaan daerah air minum (PDAM).
Pemerintah, melalui Kementerian Pekerjaan Umum menargetkan cakupan pelayanan air minum perpipaan di akhir tahun 2019 dapat mencapai $60 \%$ dari seluruh rumah tangga di Indonesia, seperti terlihat pada grafik di bawah ini.

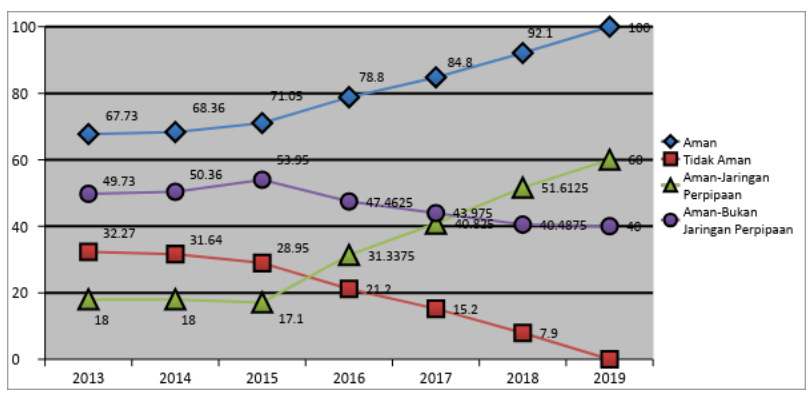

Gambar 1

Cakupan pelayanan air minum.

Dari gambar di atas terlihat bahwa upaya pemerintah untuk pencapaian universal akses dilakukan dengan cara meningkatkan cakupan pelayanan air minum berkualitas yang bersumber dari air perpipaan dari $17,1 \%$ di tahun 2015 menjadi 60\% di tahun 2019.

Pelayanan air minum perpipaan di Indonesia pada umumnya dilakukan oleh perusahaan daerah air minum (PDAM). Saat ini terdapat total 371 PDAM di seluruh Indonesia sehingga setiap upaya pencapaian air minum berkualitas yang bersumber dari air perpipaan tidak pernah bisa lepas dari upaya untuk meningkatkan cakupan pelayanan dari masing masing PDAM tersebut. 
Berdasarkan data audit kinerja PDAM seluruh Indonesia yang dipublikasikan setiap tahunnya oleh Badan Peningkatan Penyelenggaraan Sistem Penyediaan Air Minum (BPPSPAM) Kementerian Pekerjaan Umum dan Perumahan Rakyat. BPPSPAM membagi PDAM-PDAM Indonesia menjadi 4 wilayah:

- Wilayah 1 : PDAM-PDAM yang ada di Pulau Sumatera,

- Wilayah 2 : PDAM-PDAM yang ada di Pulau jawa

- Wilayah 3 : PDAM-PDAM yang ada di Pulau Sulawesi dan Kalimantan

Wilayah 4 : PDAM-PDAM diluar wilayah 1-3 yang mencakup, Bali, Nusa Tenggara, Maluku dan Papua.

Cakupan pelayanan rata rata PDAM di setiap wilayah dapat dilihat pada Tabel 1.

Tabel 1.

Cakupan Pelayanan rata-rata PDAM tiap wilayah di Indonesia (BPPSPAM, [2])

\begin{tabular}{|c|c|c|c|}
\hline \multirow{2}{*}{ Wilayah } & \multicolumn{3}{|c|}{ Rata -Rata Cakupan Pelayanan } \\
\cline { 2 - 4 } & 2014 & 2015 & 2016 \\
\hline Wilayah 1 & $37,19 \%$ & $38,15 \%$ & $38,62 \%$ \\
\hline Wilayah 2 & $47,92 \%$ & $42,01 \%$ & $43,49 \%$ \\
\hline Wilayah 3 & $44,76 \%$ & $58,47 \%$ & $46,20 \%$ \\
\hline Wilayah 4 & $43,07 \%$ & $46,38 \%$ & $49,95 \%$ \\
\hline
\end{tabular}

Masih rendahnya cakupan pelayanan dapat diakibatkan oleh dua hal yaitu: permasalahan internal PDAM sendiri, misalnya PDAM belum mampu menghasilkan keuntungan sehingga tidak mempunyai cukup dana untuk pengembangan dan (2) permasalahan eksternal, seperti tidak adanya/rendahnya penyertaan modal dari pemilik (Pemerintah Kota/Kabupaten) kepada PDAM yang mengekibatkan PDAM tidak mampu mengembangkan atau memperluas cakupan pelayanannya.

Untuk dapat mengetahui seperti atau sebesar apa pengaruh internal PDAM dalam meningkatkan cakupan pelayanan nya, maka perlu diketahui sejauh mana pengaruh variabel/indikator internal PDAM dalam peningkatan cakupan pelayanan.

Secara umum, BPKP membagi indikator dalam 4 aspek, yaitu aspek keuangan, pelayanan, operasional dan sumber daya manusia (SDM). Penelitian ini akan mengkaji secara statistik, korelasi dan determinasi antara indikator/ variabel internal dan sebesar apa pengaruh variabel internal tersebut terhadap cakupan pelayanan.

\section{METODOLOGI}

Penelitian ini ditujukan untuk mengetahui faktor-faktor yang berpengaruh pada cakupan pelayanan pada suatu PDAM dengan menggunakan analisis statistik sebagai berikut:

\section{a. Analisis Regresi Berganda (Multiple Regression)}


Analisis regresi berganda adalah analisis yang digunakan peneliti, bila bermaksud meramalkan bagaimana keadaan (naik turunnya) variable dependen (kriterium), bila dua atau lebih variable independen sebagai faktor prediktor dimanipulasi (dinaikan dan diturunkan nilainya), (Sugiyono, [3]).

\section{b. Hasil Uji Signifikansi Parsial (Uji t)}

Pengujian hipotesis secara parsial dimaksudkan untuk menganalisis bila peneliti bermaksud mengetahui pengaruh atau mengetahui hubungan antara variabel independen dengan variabel dependen, dimana salah satu variabel independennya dibuat tetap/dikendalikan. Jadi korelasi parsial merupakan angka yang menunjukkan arah dan kuatnya hubungan antara dua variabel atau lebih, setelah satu variabel yang diduga dapat mempengaruhi hubungan variabel tersebut tetap/dikendalikan [3].

\section{c. Hasil Uji Signifikan Simultan (Uji F)}

Uji Statistik $F$ atau uji linearitas adalah pengujian hipotesis tentang koefisien regresi, yaitu arah b sama dengan nol dibandingkan dengan koefisien arah regresi tidak sama dengan nol). Pengujian linearitas dieprlukan beberapa kelompok data yang setiap kelompok terdiri dari beberapa data yang sama pada data $\mathrm{X}$ dan pasangan data $\mathrm{Y}$. Setiap kelompok data $\mathrm{X}$ terdiri dari $\mathrm{n}$ data berpasangan dengan $\mathrm{Y}$ yang datanya berbeda, (Susetyo, [4]).

\section{d. Koefisien determinasi $\left(\mathbf{R}^{2}\right)$}

Koefisien determinasi merupakan proporsi untuk menentukan terjadinya persentase variansi bersama antara variabel $X$ dengan variabel $Y$ jika dikalikan dengan $100 \%$. Oleh karena itu, besarnya koefisien determinasi adalah $0 \leq r^{2} \leq 1$ dan tidak ada koefisien determinasi yang bertanda negatif karena dikuadratkan [4].

\section{e. Tabel ANOVA}

ANOVA atau Analysis of Variance adalah prosedur perhitungan yang mencoba menganalisis varian dari responden atau hasil perlakuan dari sekelompok data dari variabel independen. Analisis varian membandingkan seluruh variabel yang diteliti sekaligus, sehingga dapat memperkecil kesalahan yang mungkin terjadi dibandingkan dengan menggunakan uji-t. Analisis varian merupakan perluasan dari uji-t, karena dapat melakukan pengujian perbandingan tiga atau lebih variabel penelitian sekaligus [4].

Data yang digunakan dalam penelitian ini merupakan data sekunder yang diambil Buku hasil audit kinerja PDAM yang dipublikasikan oleh BPPSPAM Kementerian Pekerjaan Umum dan Perumahan tahun buku adalah tahun 2017 sedangkan audit kinerja sendiri 
dilakukan oleh Badan Pemeriksa Keuangan Provinsi (BPKP) pada akhir tahun 2016. Untuk variabel input-nya (variabel bebas) yang digunakan adalah:
a. Rasio Operasi
b. Kualitas Air Pelanggan
c. Konsumsi Air Domestik
d. Efisiensi Produksi
e. Tingkat Kehilangan Air
f. Rasio Jumlah Pegawai/ 1000 Pelanggan

Rasio Operasi (RO) adalah indikator yang dapat menunjukan sejauhmana manajemen PDAM dapat melakukan efisiensi /pengendalian biaya operasi dan sejauhmana manajemen PDAM dapat melakukan upayaupaya peningkatan pendapatannya sehingga mampu menghasilkan pendapatan yang cukup untuk menutup biaya operasi. Secara teoritis jika angka ratio operasi semakin kecil $(<0,5)$ maka artinya PDAM mempunyai pendapatan jauh di ats pengeluaran yang artinya dari pendapatannya tersebut PDAM dpat meningkatkan cakupan pelayanan.

Kualitas Air Pelanggan: Indikator ini akan menggambarkan sejauhmana PDAM telah mampu melayani pelanggannya dengan kualitas pelayanan air minum (3K) sebagaimana yang diatur dalam Peraturan Menteri Kesehatan No. 492/MENKES/PER/IV/ 2010, tentang Persyaratan Kualitas Air Minum. Semakin banyak air yang memenuhi kualitas, semakin banyak masyarakat yang ingin mendapatkan pelayanan PDAM sehingga akan mendorong semakin meluasnya cakupan pelayanan.

Konsumsi Air Domestik: Indikator ini untuk mengetahui tingkat rata-rata konsumsi air per pelanggan rumah tangga dalam satu bulan dalam tahun yang bersangkutan. Apabila konsumsi air per pelanggan rumah tangga semakin banyak, maka pendapatan PDAM akan semakin meningkat, dengan demikian PDAM akan mempunyai cukup dana untuk memperluas cakupan pelayanan.

Efisiensi Produksi: adalah salah satu indikator yang menunjukan sejauhmana efisiensi PDAM dalam memanfaatkan kapasitas terpasangnya. Semakin efisien artinya PDAM semakin optimal dalam memanfaatkan kapasitas terpasangnya sehingga akan semakin banyak pelanggan yang dapat dilayani.

Tingkat Kehilangan Air: Kehilangan Air/ Tidak Berekening adalah salah satu indikator yang menunjukan sejauhmana manajemen PDAM mampu mengendalikan penjualan barang produknya yaitu air minum melalui sistem distribusi perpipaan. Tingkat kehilangan air yang tinggi akan menyebabkan banyak hal, diantaranya air yang yang tebayar menjadi lebih kecil. Dengan demikian, apabila PDAM dapat memperkecil kehilangan air, 
maka air yang terjual menjadi lebih banyak, pendapatan menjadi meningkat dan akan mempunyai cukup dana untuk pengembangan/ perluasan cakupan pelayanan.

\section{Rasio Jumlah Pegawai/1000 Pelanggan:} Indikator ini digunakan untuk mengukur efisiensi pegawai PDAM terhadap pelanggan. Pengeluaran PDAM untuk membayar karyawan adalah salah satu biaya terbesar di setiap PDAM selain biaya untuk bahan kimia dan biaya listrik. Dengan rasio jumlah pegawai /1000 pelanggan yang lebih kecil maka biaya operasional berbanding air yang diproduksi menjadi lebih kecil, sehingga pendapatan menjadi lebih besar.

Untuk menganalisa hubungan Cakupan Pelayanan dengan beberapa variable yang dianggap berpengaruh maka digunakan analisis regresi berganda sebagai alat bantu. Adapun langkah proses yang dilakukan adalah sebagai berikut:

\section{a. Penentuan Variabel}

Hal yang pertama kali dilakukan yaitu mengidentfikasi variabel - variabel yang ada. Dalam studi ini yang menjadi variable dependen atau terikat adalah cakupan pelayanan, sementara variable independen atau bebas terdiri dari rasio operasi, kualitas air pelanggan, konsumsi air domestik, efisiensi produksi, tingkat kehilangan air, dan rasio jumlah pegawai/1000 pelanggan.

\section{Variabel Dependen}

$\mathrm{Y}=$ Cakupan Pelayanan

\section{Variabel Independen}

X1 = Rasio Operasi

X2 = Kualitas Air Pelanggan

X3 = Konsumsi Air Domestik

X4 - Efisiensi Produksi

X5 $=$ Tingkat Kehilangan Air

X6 = Rasio Jumlah Pegawai/1000 Pelanggan

b. Model Regresi

c. Menguji keberartian variable model regresi:

- $\quad$ Simultan \& Koefisien Determinasi

- $\quad$ Parsial \& Koefisien Determinasi

Pada penelitian ini, nilai dari variable- variable di atas merupakan nilai dari 371 PDAM yang diperiksa oleh BPKP pada tahun 2016. Analisis dilakukan dengan menggunakan software SPSS versi 21.

\section{ANALISIS DAN PEMBAHASAN}

Seperti telah disebutkan di atas, terdapat 6 faktor yang diuji pengaruhnya dengan cakupan pelayanan, yaitu:

- Rasio Operasi

- Kualitas Air Pelanggan

- Konsumsi Air Domestik

- Efisiensi Produksi

- Tingkat Kehilangan Air 
- Rasio Jumlah Pegawai/ 1000 Pelanggan

Dengan menggunakan alat statistik Multiple Regression, ditentukan beberapa hal sebagai berikut:

\section{a. Hipotesis}

- H0 : Tidak terdapat hubungan secara simultan antara Cakupan Pelayanan dengan keenam variabel tersebut

- H1 : Terdapat hubungan secara simultan antara Cakupan Pelayanan dengan keenam variabel tersebut $\alpha=$ $5 \%$

\section{b. Statistik Uji}

Statistik uji menggunakan taraf signifikansi tabel ANOVA

\section{c. Kriteria Uji}

Tolak HO jika Signifikansi pada table ANOVA jika Sig. $<5 \%$

Tabel 2.

ANOVA

\begin{tabular}{|c|c|c|c|c|c|c|}
\hline \multicolumn{2}{|r|}{ Model } & $\begin{array}{c}\text { Sum of } \\
\text { Squares }\end{array}$ & df & $\begin{array}{c}\text { Mean } \\
\text { Square }\end{array}$ & $F$ & Sig. \\
\hline \multirow{3}{*}{1} & Regression & 4.240 & 6 & .707 & 16.322 & $.000 \mathrm{~b}$ \\
\hline & Residual & 15.759 & 364 & .043 & & \\
\hline & Total & 19.998 & 370 & & & \\
\hline
\end{tabular}

a. Dependent Variable: Cakupan_Pelayanan

b. Predictors: (Constant), Rasio_Jumlah_Pegawai,

Konsumsi_Air_Domestik, Kualitas_Air_Pelanggan,

Tingkat_Kehilangan_Air,Rasio_Operasi,

efisiensi_Produksi

Berdasarkan analisis di atas karena Signifikansi ANOVA, $000^{\mathrm{b}}<5 \%$ maka $\mathrm{H}_{0}$ ditolak.
Dari hasil perhitungan dengan SPSS juga diperoleh tabel korelasi seperti terlihat pada Tabel 3.

Tabel 3.

Model Summary

\begin{tabular}{|c|c|c|c|c|}
\hline Model & $\mathrm{R}$ & $\begin{array}{c}\mathrm{R} \\
\text { Square }\end{array}$ & $\begin{array}{c}\text { Adjusted } \\
\mathrm{R} \text { Square }\end{array}$ & $\begin{array}{c}\text { Std. Error } \\
\text { of the } \\
\text { Estimate }\end{array}$ \\
\hline 1 & $.460^{\mathrm{a}}$ & .212 & .199 & .2080688 \\
\hline
\end{tabular}

a. Predictors: (Constant), Rasio_Jumlah_Pegawai,

Konsumsi_Air_Domestik, Kualitas_Air_Pelanggan,

Tingkat_Kehilangan_Air, Rasio_Operasi, Efisiensi_Produksi

Berdasarkan tabel diatas didapat nilai korelasi $R=0,460$, artinya secara simultan keenam variabel independen memiliki hubungan cukup.

Tabel 4.

Korelasi (Guilford, 1956)

\begin{tabular}{|c|c|}
\hline Koefisien korelasi $\mathbf{r}$ & Interpretasi \\
\hline $0,80-1,00$ & Sangat Tinggi \\
\hline $0,60-0,80$ & Tinggi \\
\hline $0,40-0,60$ & Cukup \\
\hline $0,20-0,40$ & Rendah \\
\hline $0,00-0,20$ & Sangat Rendah \\
\hline
\end{tabular}

Dengan nilai korelasi $R=0.460$ maka didapat nilai koefisien determinasi $R^{2}=0,212$ yang artinya keenam variabel tersebut berkontribusi sebesar 21,2\% terhadap nilai cakupan pelayanan, sementara sisanya dipengaruhi oleh variabel yang lain.

Dengan taraf signifikansi 5\% diperoleh hasil bahwa secara nasional terdapat hubungan secara simultan antara Cakupan Pelayanan dengan keenam variabel tersebut. 
Berdasarkan nilai korelasi, maka secara statistic, keenam variable berkontribusi sebesar $21,2 \%$ terhadap nilai cakupan pelayanan.

Dengan menggunakan alat Simple Regression ditentukan beberapa hal sebegai berikut:

\section{a. Hipotesis}

$\mathrm{H}_{01}$ : Tidak terdapat hubungan antara Cakupan

Pelayanan dengan Rasio Operasi

$\mathrm{H}_{11}$ : Terdapat hubungan antara Cakupan Pelayanan dengan Rasio Operasi
$\mathrm{H}_{06}$ : Tidak terdapat hubungan antara Cakupan Pelayanan dengan Rasio Jumlah Pegawai/1000 Pelanggan

$\mathrm{H}_{16}$ : Terdapat hubungan antara Cakupan Pelayanan dengan Rasio Jumlah Pegawai/1000 Pelanggan

$\alpha=5 \%$

\section{b. Statistik Uji}

Statistik Uji t

\section{c. Kriteria Uji}

Tolak $\mathrm{H}_{0}$ jika Signifikansi pada tiap row variable jika Sig.<5\%

Tabel 5.

Coefficients $^{\mathrm{a}}$

\begin{tabular}{|c|c|c|c|c|c|c|c|c|}
\hline \multicolumn{2}{|c|}{ Model } & \multicolumn{2}{|c|}{$\begin{array}{c}\text { Unstandardized } \\
\text { Coefficients }\end{array}$} & \multirow{2}{*}{$\begin{array}{c}\begin{array}{c}\text { Standardized } \\
\text { Coefficients }\end{array} \\
\text { Beta }\end{array}$} & \multirow[t]{2}{*}{$\mathrm{t}$} & \multirow[t]{2}{*}{ Sig. } & \multicolumn{2}{|c|}{ Correlations } \\
\hline & & $B$ & $\begin{array}{l}\text { Std. } \\
\text { Error }\end{array}$ & & & & Zero-order & Partial \\
\hline \multirow{7}{*}{1} & (Constant) & .327 & .063 & & 5.208 & .000 & & \\
\hline & Rasio_Operasi & .013 & .017 & .042 & .774 & .440 & -.199 & .041 \\
\hline & Kualitas_Air_Pelanggan & .040 & .025 & .079 & 1.597 & .111 & .208 & .083 \\
\hline & Konsumsi_Air_Domestik & .007 & .003 & .160 & 2.919 & .004 & .287 & .151 \\
\hline & Efisiensi_Produksi & .140 & .062 & .130 & 2.259 & .024 & .315 & .118 \\
\hline & Tingkat_Kehilangan_Air & -.061 & .094 & -.036 & -.648 & .517 & -.217 & -.034 \\
\hline & Rasio_Jumlah_Pegawai & -.013 & .003 & -.285 & -4.663 & .000 & -.382 & -.237 \\
\hline
\end{tabular}

a. Dependent Variable: Cakupan_Pelayanan

Dengan taraf signifikansi 5\% diperoleh hasil bahwa yang terdapat hubungan secara parsial dengan Cakupan Pelayanan adalah variable Konsumsi Air Domestik, Efisiensi Produksi, dan Rasio Jumlah Pegawai.

Sementara untuk korelasinya adalah sebagai berikut:

- Korelasi antara Cakupan Pelayanan dengan Konsumsi Air Domestik adalah $\mathbf{0 , 1 5 1}$. Untuk Koefisien Determinasinya adalah 2,28\% artinya Konsumsi Air Domestik berkontribusi 2,28\% terhadap Cakupan Pelayanan, sementara sisanya dipengaruhi oleh variable lain.

- Korelasi antara Cakupan Pelayanan dengan Efisiensi Produksi adalah 0,118. Untuk Koefisien Determinasinya adalah 1,39\% artinya Efisiensi Produksi berkontribusi $1,39 \%$ terhadap Cakupan Pelayanan, sementara sisanya dipengaruhi oleh variable lain 
- Korelasi antara Cakupan Pelayanan dengan Rasio Jumlah Pegawai adalah 0,237. Untuk Koefisien Determinasinya adalah 5,6\% artinya Rasio Jumlah Pegawai berkontribusi $5,6 \%$ terhadap Cakupan Pelayanan, sementara sisanya dipengaruhi oleh variable lain

Selain cakupan pelayanan ditinjau dari luas daerah dan banyaknya pelanggan, PDAM perlu meningkatkan kualitas pelayanan terhadap pelanggan (Hariadi dkk, [5]). Tingkat kepuasan pelanggan PDAM dipengaruhi oleh aspek pelayanan yang terdiri dari reliability, assurance, tangibles, empathy, dan responsiveness (Sudirman, [6]).

\section{KESIMPULAN}

Berdasarkan hasil analisis statistik di atas, dapat disimpulkan sebagai berikut :

a. Variabel internal PDAM secara simultan mempunyai pengaruh yang signifikan terhadap cakupan pelayanan. Apabila kondisi keenam variable secara dioptimalkan simultan, maka akan dapat meningkatkan cakupan pelayanan sebesar $21,2 \%$.

b. Apabila upaya optimalisasi dilakukan secara parsial, maka variable yang dapat secara langsung mempengaruhi cakupan pelayanan adalah variable konsumsi air domestic, efisiensi produksi dan rasio jumlah pegawai/1000 pelanggan. c. Optimalisasi yang dilakukan secara parsial tidak memberikan pengaruh yang besar terhadap cakupan pelayanan. Memperbaiki konsumsi air domestik hanya dapat meningkatkan cakupan pelayanan sebesar 2,28\%, effisiensi produksi sebesar $1,39 \%$ dan perbaikan rasio jumlah pegawai hanya berkontribusi sebesar 5,6\%.

d. Dengan demikian apabila PDAM ingin meningkatkan cakupan pelayanan maka yang diperlukan adalah upaya perbaikan seluruh variabel yang dilakukan secara simultan.

\section{DAFTAR PUSTAKA}

[1] Kementrian Kesehatan Republik Indonesia, 2015. Profil Kesehatan Indonesia.

[2] BPPSPAM Kementerian Pekerjaan Umum dan Perumahan, Laporan Audit Kinerja PDAM 2015-2017.

[3] Sugiyono, 2017. Statistika untuk Penelitian, Penerbit Alfabeta.

[4] Susetyo, B. 2012. Statistika untuk Analisis Data Penelitian, Penerbit Reflika Aditama.

[5] Hariadi, P., Ramadhanti, W. 2008. Kualitas Pelayanan Perusahaan Air Minum Daerah (PDAM) Kabupaten Banjarnegara, Purbalingga, Banyumas, dan Cilacap. Jurnal Manajemen, 
Infomatek Volume 20 Nomor 2 Desember 2018 : 69 - 78

Akuntansi dan Bisnis, Volume 6, No. 1.

Jurnal Spread, Volume 2 No. 1, hal.

[6] Sudirman. 2012. Pengaruh Kualitas 85-98.

Pelayanan PDAM Kota Makassar. 